\title{
Factors affecting the adoption of human resource information system (HRIS) in Bangladesh: A study on private banking industry
}

\author{
Sumon Das ${ }^{1}$, Shilpi Das ${ }^{2} \&$ Popy Rani Sarkar ${ }^{3}$ \\ ${ }^{1}$ Department of Management University of Dhaka \\ ${ }^{2}$ Department of Accounting \& Information Systems, Jagannath University \\ ${ }^{3}$ Department of Management, University of Dhaka
}

\begin{abstract}
Adoption of Human Resource Information System is the significant issue in banking sector from last decade though it is the challenge for developing countries like Bangladesh to adopt HRIS successfully. The purpose of this study is to find out different driving and restraining factors that affect the adoption of HRIS in Bangladesh from private banking perspective. Data were collected from 52 respondents of 18 private banks operating in Bangladesh through a structured questionnaire including 12 questions. Different statistical tools such as correlation, regression analysis, anova, co-efficients, hypothesis tests have been used that has showed that there is a positive relationship between driving factors and HRIS adoption in private banking sector in Bangladesh that refers these driving factors support the organization to adopt the HRIS in its function and explore the benefits of its usage successfully while there exists negative relationship between restraining factors and adoption that becomes the challenge for the banking sector to adopt HRIS specially by developing countries like Bangladesh. The study suggests that as HRIS is both the beneficial and challenging issue for Bangladesh, the organization should concern about the adoption and proper usage of HRIS so that it can lead to the better performance of the organization.
\end{abstract}

Keywords - HRIS, Factors, Adoption, Private Banking Industry, Bangladesh. 


\section{Introduction}

Information technology is now the most significant way for the endurance of the organizations. Every organization prioritizes the innovative techniques through IT for different activities not only in HR department but also in other departments (Hanif, Yunfei, Hanif, Muhammad, Ahmed and Xiu-Yin, 2014). Now the activities have shifted from manual to automatical ways (Florkowski and Olivas, 2006) so there arises a high need of human resource information systems that is the way of functioning in an effective and efficient manner (Nusair and Parsa, 2007) that the organizations adopts for overall activities also to facilitate with its strategic and administrative benefits.

Human resource management is one of the most prioritized tasks of the organizations (Al Shibly H., 2011) that use human resource information system to complete the HR functions. It gives the accuracy and reliability of human resource related information. HRIS adoption has got a significant increase in different organizations from the last decade (Ball, 2001; Barron et al., 2004) and is an important element in banking sector (Hendrickson, 2003). But the adoption of HRIS in Bangladesh and also in other developing countries has become a challenge (Ginzberg, 1981) because of the limited knowledge of its successful usage and outcome.
The key role of HRIS in banking sector is to work with information of HR that is time saving and updated system. For that banking sector needs the adoption of HRIS in Bangladesh. The main objective of this research is to find out the affecting factors to the adoption of HRIS in banking sector in context of Bangladesh. Positive and negative factors come in respect of the adoption of HRIS that need to be faced in an effective way by organization (ChauandTam, 1997).

The adoption of HRIS needs high cost but it should be considered as investment not as an expense (Gardner et.al, 2003) because later this will provide better outcome that is long term profitable for the organization. For the expunction of firms operation to abroad, it is the first and special sense to expand HRIS in the firms operation for the foreign countries firms (Dessler, 2012). This paper will show the survey results in an organized way including literature review which reveals the previous literature relevant to this study. Also it covers the research methodology that shows how the primary and secondary data have been collected and how these will be analyzed in findings and analysis part with hypothesis testing for more valid analysis. This paper also includes a concluding part that shows the limitation of this study and additionally parades how this study will be benignant for future research. 


\section{Literature review}

Human resource information system is a systematic way for performing different types of activities for businesses related to human resource, accounting, and management through software. Human resource and information system combine the term Human resource information system in short HRIS through software. HRIS also refers the union of software, hardware and database that is used to store different data of different departments and to use the requisite information in the demand of the human resource department (Broderick \& Boudreau, 1991). It is mainly used for the collection, skillful handling, proper analysis, and allotment of relevant information about human resource (Tannenbaum, 1990). The adequate skilled human resource with previous knowledge necessary to HRIS is a main considerable factor in the adoption of HRIS in any organization.

Proper application and implementation of IS in HRM is an effective way to run a good business in the present competitive world (Zhang and Wang, 2006). Banking industry is not out of that. Banking sector in Bangladesh is adopting the HRIS in its human resource department. There are lots of limitations in implementing HRIS including inefficient bio-data system, lack of skilled human resource (Ambira \& Kemoni, 2011). At the beginning of $21 \mathrm{st}$ century HRIS was successfully adopted by developed countries. But in developing countries like Bangladesh adoption of HRIS has been implemented in last 10 years (Jahan, 2014). Bangladesh is going ahead gradually to adopt the benefits of HRIS. Government of Bangladesh is also taking this matter into consideration and the aim of adopting HRIS is similar in both manufacturing and service organization like banking sector (Bhuiyan\&Rahman, 2014).

The study shows some factors affecting the adoption of HRIS in banking sector that have been found out from previous research. Factors can be considered as both possibility of benefits and barriers (ChauandTam, 1997). Some are driving factors which instigate the adoption of HRIS in the organization coupled with some restraining factors that limit the adoption of HRIS. IS infrastructure can be called as the technological readiness if the organization has proper knowledge in IT adoption and application and in human resource management and if there is proper IT infrastructure in HRM, the organization will adopt HRIS in its Human resource department. ((Iacovou et al., 1995). According to different previous research, degree of decentralization can encourage adoption (Grover, 1993) and at the same time also can hinder the adoption of HRIS (Hage\& Aiken, 1969). 
There is a positive relation between top management support and HRIS adoption (Premkumar and Roberts, 1999, Yap, 1989) as well as HR expertise and adoption of HRIS (Chau and Hui, 2001, Kwon and Zmud, 1987). There is a strong relationship between external network and the adoption of HRIS in any organization (Sykes et al., 2009).

Environmental factors are most likely to affect the adoption of IS in HR (Chong, 2001). Any business organization like banking industry operates within an environment and external competition, social influence, government regulation and industry characteristics comprise these external environmental factors (DePietro et al., 1990, Oliveira and Martins, 2010).Degree of individuals belief about others thinking for adopting new way is called social influence ((Venkatesh et al., 2003) and it has a positive relation with the adoption of HRIS (Venkatesh., Morris., Davis, 2003). Competitive environment precedes the adoption of HRIS but is not the significant factor. Bangladesh government also concerns about the adoption of HRIS in banking sector.

HRIS brings some relative advantage like advanced accuracy system, timely and quick access to information, (Wille\& Hammond, 1981; Lederer, 1984) that refers the competitive strength of something for the adopters and this plays a great role in adopting
HRIS by organization (Premkumar and Roberts, 1999). The degree of individuals' belief about the information systems' efficiency and better performance refers the performance expectancy and for better performance and quality service, the organizations intend to adopt the HRIS in human resource departments (Venkatesh et al., 2003).

Furthermore, some restraining factors affect the adoption of HRIS. Difficulty in the usage of IS refers to the complexity that is the hindrance due to lack of skills and experience (Rogers, 2003, 1983) and this has negative relation with the adoption of IS in HR department (Tornatzky\& Klein, 1982, Grover \& Goslar, 1993). The outcome of any IS should be observable to others and this affects in its adoption (Rogers, 1995). HRIS causes the automation of HR activities from manual way but there is always resistance by the employees of the organizations for different reasons that become the challenge for the adoption of HRIS (Teo\&Pian, 2003). So HRIS should be compatible with organizations' present strategy (King \&Teo, 1996).HRIS adoption and implementation needs better financial conditions of the firms. For that larger organization can easily implement it than smaller firms but matter to be pointed out that smaller organizations are more nimble to adopt it for flexibility 
(Barbosa and Musetti, 2010). Advantages from the proper implementation of HRIS become the major concern for the organizations before adopting this (Troshani, Jerram, and Gerrard , 2010) and among the benefits of its adoption, quick response to the needs and full access to information are the major benefits (Ngai and Wat, 2006).

Many authors have explored factors affecting HRIS in different sectors such as in Telecom Sector in Pakistan (Hanif, Yunfei, Hanif, Muhammad, Ahmed and Xiu-Yin, 2014), in SMEs in Cameroon (Fobang, Wamba and Kamdjoug, 2016), in public sector in Australia (Troshani, Jerram and Hill, 2011), in Bangladeshi banking and financial sector (Rahman, Qi and Jinnah, 2016), in Bangladesh (Khan, Hasan, Rubel, 2015), (AlDmour, Love, Al-Zu'bi, 2013). The previous studies also focused many

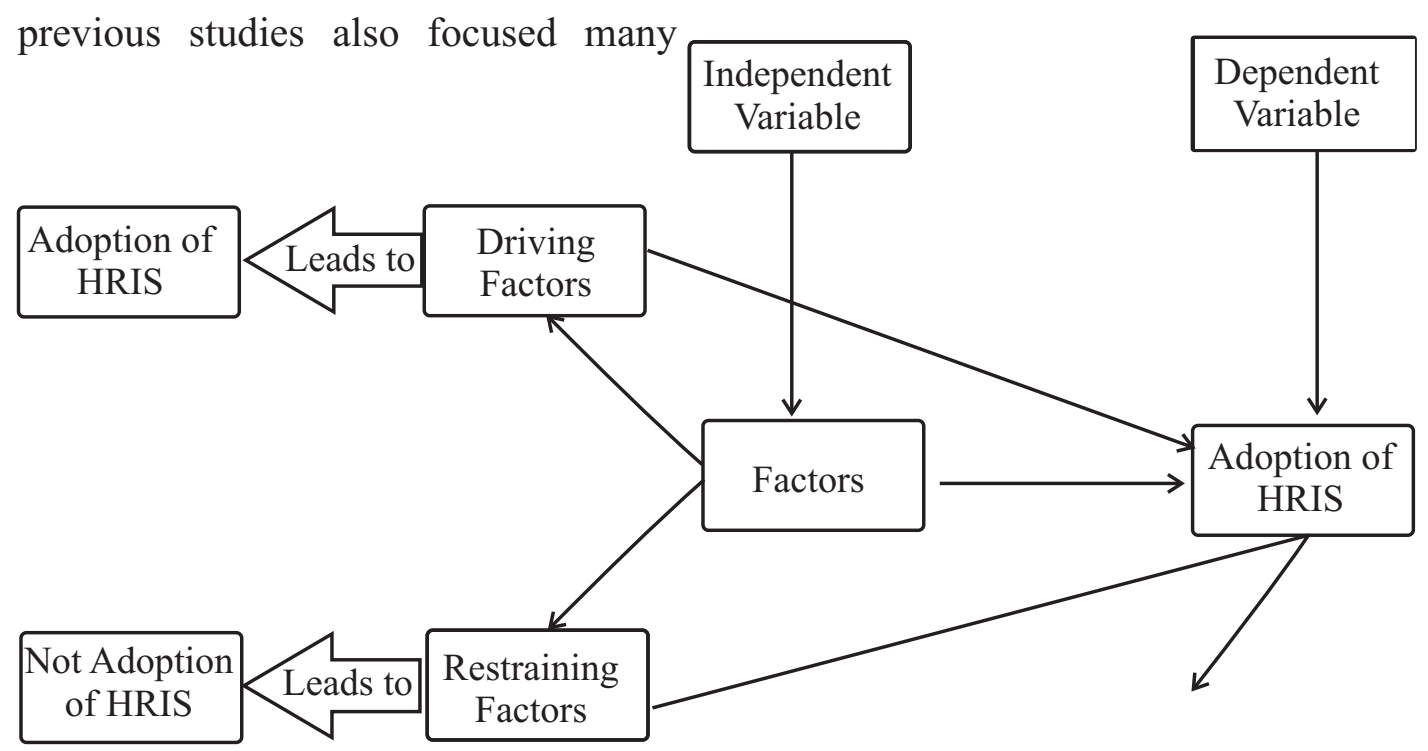

Figure1.Proposed research model factors affecting HRIS in organization like top management support (Premkumar and Roberts, 1999; Yap, 1989), HR expertise (Chau and Hui, 2001; Kwon and Zmud, 1987; Warren, 2004), quick response and access of information (Ngai and Wat, 2006), quality of outcomes of HRIS (AlTarawneh, 2012). But this study has focused on the factors that are affecting HRIS in private banking sector in context of Bangladesh

\subsection{Proposed research model building}

Model is a complete set of variables including dependent and independent variables that are related to each other in a systematic manner for better under standing of others (Greenhaus, 2006). The proposed model of this study has been shown in the following for better understanding: 
The model shows the independent variable that is "Factors" includes two; driving factors and restraining factors and one dependent variable that is "Adoption of HRIS". As per the model, driving factors lead to the adoption of HRIS in the organization while restraining factors lead to the notadoption of HRIS means these factors hinder the adoption. This study considers seven factors as driving factors including HRIS expertise and knowledge, IS infrastructure, support of higher authority, external network availability, competitive environment, better performance and quality service, government regulation as well as three factors as restraining factors including resistance from employees, complexity, higher cost.

\section{Research methodology}

The study focuses on the factors that affect in adopting HRIS by private banking industry in Bangladesh. The study covered 52 total numbers of respondents where bank job holders of different private banks operating in Bangladesh were selected as sample. Data has been collected from both primary and secondary sources. Primary data has been collected from the bank job holders by providing a structured questionnaire on a five point likert scale including 12 questions related to driving and restraining factors (ChauandTam, 1997) with 5 general questions about respondents and banks of the respondents and Secondary data has been collected from different books, articles, journals, websites etc.

The study has included two variables; independent variable including driving factors that include 7 relevant issues and restraining factors include 3 relevant issues and dependent variable including adoption of HRIS by organization. Here another issue that is not-adoption of HRIS has also been included for better understanding of the relationship between dependent and independent variable.

The result has been analyzed by using SPSS (Statistical package for Social Sciences, version-22), Microsoft word \& Microsoft excel. Descriptive statistics has been used to show the narrative view of the result. In addition to that the study covers co-relation, regression analysis, ANOVA, coefficients. Hypothesis has also been showed to test the relationship between dependent and independent variable. 


\section{Findings and analysis}

Table 1. Demographic characteristics of respondents

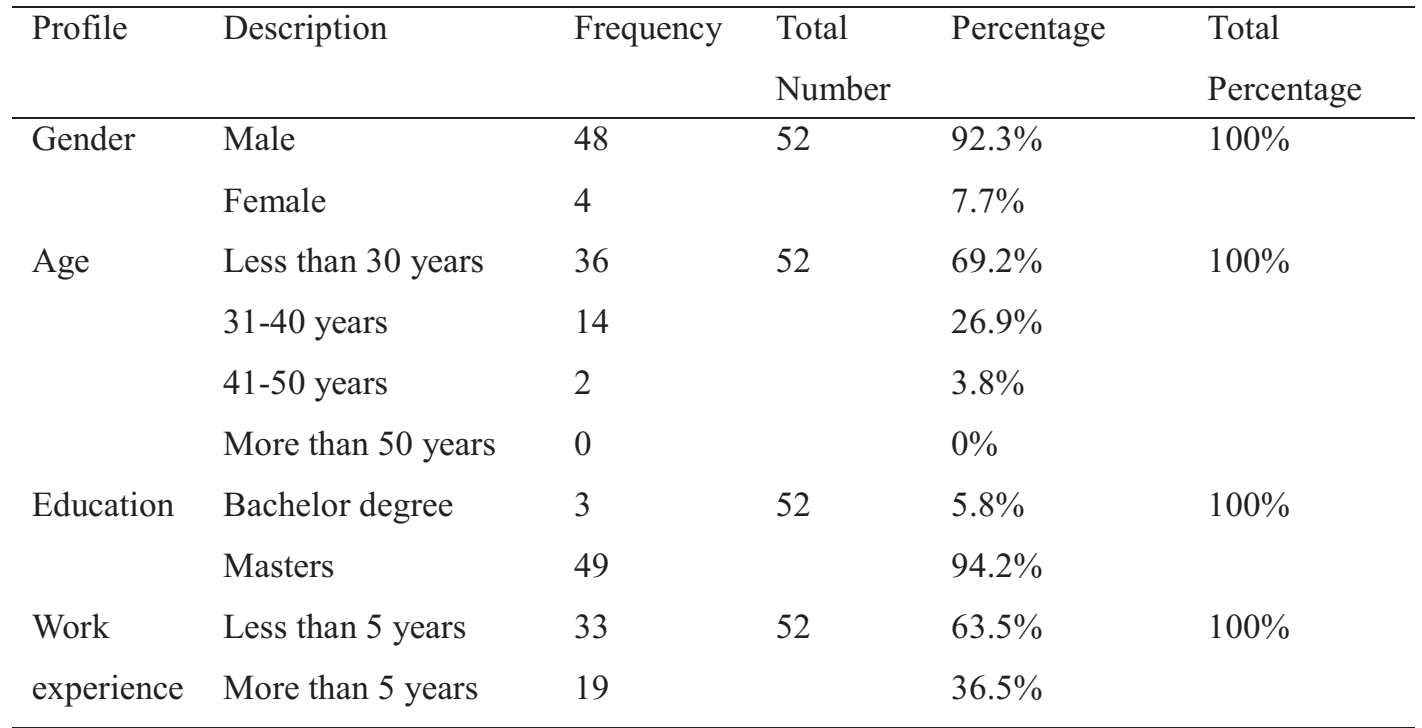

Source: Field survey

Table 2. Descriptive statistics

\begin{tabular}{lllllll}
\hline & N & Minimum & Maximum & Mean & Std. Deviation & Variance \\
\hline DF & 52 & 17.00 & 35.00 & 28.0769 & 3.45756 & 11.955 \\
RF & 52 & 6.00 & 15.00 & 10.7308 & 2.36075 & 5.573 \\
Q1 & 52 & 1 & 5 & 4.19 & .864 & .747 \\
Q2 & 52 & 3 & 5 & 4.29 & .696 & .484 \\
Q3 & 52 & 2 & 5 & 4.52 & .700 & .490 \\
Q4 & 52 & 1 & 5 & 3.77 & .854 & .730 \\
Q5 & 52 & 2 & 5 & 4.06 & .802 & .644 \\
Q6 & 52 & 3 & 5 & 4.25 & .653 & .426 \\
Q7 & 52 & 1 & 5 & 3.00 & 1.205 & 1.451 \\
Q8 & 52 & 1 & 5 & 3.37 & 1.010 & 1.021 \\
Q9 & 52 & 1 & 5 & 3.54 & 1.038 & 1.077 \\
Q10 & 52 & 1 & 5 & 3.83 & 1.133 & 1.283 \\
ADP & 52 & 1 & 5 & 3.77 & 1.041 & 1.083 \\
NADP & 52 & 1 & 5 & 3.37 & 1.172 & 1.374 \\
Valid N (listwise) & 52 & & & & & \\
\hline N6 DF Diving & & & & & & \\
\hline
\end{tabular}

Note: $\mathrm{DF}=$ Driving Factors, $\mathrm{RF}=$ Restraining Factors, $\mathrm{ADP}=$ Adoption of HRIS, NADP $=$ Not Adoption of HRIS.

International Journal of Accounting \& Business Finance - 07 - 
Descriptive statistics shows the narrative view of the contents including in a study. The upper table exhibits mean, standard deviation, variances, minimum, maximum of all the variables in this study that gives the summarized idea about this study.

\subsection{Correlations and regression analysis: adoption of HRIS, driving and restraining factors}

Table3. Correlations

\begin{tabular}{lllll}
\hline & & ADP & DF & RF \\
\hline \multirow{2}{*}{$\begin{array}{lllll}\text { Pearson } \\
\text { Correlation }\end{array}$} & ADP & 1 & 0.359 & - \\
& DF & 0.359 & 1 & 0.098 \\
& RF & -0.098 & 0.252 & 1 \\
Sig. $\quad(1-$ & ADP &. & 0.004 & 0.246 \\
tailed $)$ & DF & 0.004 &. & 0.036
\end{tabular}

$\begin{array}{lllll} & \text { RF } & 0.246 & 0.036 & \cdot \\ & \text { ADP } & 52 & 52 & 52 \\ \mathrm{~N} & \text { DF } & 52 & 52 & 52 \\ & \text { RF } & 52 & 52 & 52\end{array}$

Table3 shows Pearson correlation between dependent variable and independent variables. Here positive corelationship exists between the adoption of HRIS and driving factors as the corelation value between them is .359 which is positive value. Additionally the table shows the co-relationship between adoption and restraining factors. Here the value is -.098 so it indicates that there is a negative corelationship between restraining factors and adoption of HRIS. Driving factors instigate the adoption while restraining factors lead to not-adoption of HRIS

Table 4. Model summary

\begin{tabular}{|c|c|c|c|c|c|c|c|c|c|}
\hline \multirow[b]{2}{*}{ Model } & \multirow[b]{2}{*}{$\mathrm{R}$} & \multirow[b]{2}{*}{$\begin{array}{l}\mathrm{R} \\
\text { Square }\end{array}$} & \multirow[b]{2}{*}{$\begin{array}{l}\text { Adjusted } \\
\mathrm{R} \\
\text { Square }\end{array}$} & \multirow{2}{*}{$\begin{array}{l}\text { Std. } \\
\text { Error of } \\
\text { the } \\
\text { Estimate }\end{array}$} & \multicolumn{5}{|c|}{ Change Statistics } \\
\hline & & & & & $\begin{array}{l}\mathrm{R} \\
\text { Square } \\
\text { Change }\end{array}$ & $\begin{array}{l}\mathrm{F} \\
\text { Change }\end{array}$ & df1 & $\mathrm{df} 2$ & $\begin{array}{l}\text { Sig. F } \\
\text { Change }\end{array}$ \\
\hline 1 & $.409^{\mathrm{a}}$ & 0.167 & 0.133 & 0.969 & 0.167 & 4.909 & 2 & 49 & 0.011 \\
\hline
\end{tabular}

Table 5. ANOVA ${ }^{\mathrm{a}}$

\begin{tabular}{lllllll}
\hline Model & & Sum of Squares & df & Mean Square & F & Sig. \\
\hline 1 & Regression & 9.219 & 2 & 4.610 & 4.909 & $.011^{\mathrm{b}}$ \\
& Residual & 46.011 & 49 & .939 & & \\
& Total & 55.231 & 51 & & & \\
\hline
\end{tabular}

a. Dependent Variable: ADP

b. Predictors: (Constant), RF, DF 
Table 4 represents $R$ square value .167 that refers how much the independent variables affect the dependent variable. Here the independent variable "Factors" positively affects the dependent variable "Adoption of HRIS" that has been represented through $\mathrm{F}$ value in Table 5.

Table 6.Coefficients

\begin{tabular}{|c|c|c|c|c|c|c|c|}
\hline \multirow{3}{*}{ Model } & \multirow{2}{*}{\multicolumn{2}{|c|}{ Unstandardized Coefficients }} & \multirow{2}{*}{\multicolumn{2}{|c|}{$\begin{array}{l}\text { Standardized } \\
\text { Coefficients }\end{array}$}} & & $95.0 \%$ & \multirow[t]{2}{*}{ Confidence } \\
\hline & & & & & & Interval for B & \\
\hline & $\mathrm{B}$ & Std. Error & \multicolumn{2}{|l|}{ Beta } & $\operatorname{Sig}$ & Jower Bound & Dound \\
\hline (Constant) & 1.256 & 1.164 & & 1.079 & .286 & -1.083 & 3.595 \\
\hline DF & .123 & .041 & .410 & 3.043 & .004 & .042 & .205 \\
\hline $\mathrm{RF}$ & -.089 & .059 & -.201 & -1.492 & .142 & -.208 & .031 \\
\hline
\end{tabular}

In the Table6, the value of B (Constant) 1.256 indicates average adoption of HRIS if there is no factor and the value of B (DF) .123 indicates the positive relationship between adoption and driving factors while value of $B(R F)$ .089 shows the negative relationship between restraining factors and adoption.

\subsubsection{Hypothesis testing: adoption of HRIS and driving factors}

$\mathrm{H}_{0}=$ No significant relationship exists between Adoption of HRIS and Driving Factors

$\mathrm{H}_{\mathrm{A}}=$ Significant relationship exists between Adoption of HRIS and Driving Factors.

The calculated value of " $\mathrm{t}$ " of $\mathrm{DF}=$ 3.043. The critical value of " $t$ " at $5 \%$ level of significance is $+2.000 \&-2.000$.
Since the calculated value of " $t$ " does not fall between these two critical values, the null hypothesis is rejected. So there is a meaningful \& significant correlation between adoption of HRIS and driving factors.

The calculated value of " $t$ " of $R F=$ 1.492. The critical value of "t" at $5 \%$ level of significance is $+2.000 \&-2.000$. Here the calculated value of " $t$ " falls between these two critical values that show the acceptance of null hypothesis. So there is no significant correlation between adoption and restraining factors.

\subsubsection{Hypothesis testing: adoption of HRIS and restraining factors}

$\mathrm{H}_{0}=$ No significant relationship exists between Adoption of HRIS and Driving Factors 
$\mathrm{H}_{\mathrm{A}}=$ Significant relationship exists between Adoption of HRIS and Driving Factors.

The calculated value of " $\mathrm{t}$ " of $\mathrm{RF}=$ 1.492. The critical value of " $t$ " at $5 \%$ level of significance is $+2.000 \&-2.000$. Here the calculated value of " $t$ " falls between these two critical values that show the acceptance of null hypothesis. So there is no significant correlation between adoption and restraining factors.

\subsection{Correlationsand regression} analysis: not-adoption of HRIS, driving and restraining factors

\begin{tabular}{lllll}
\hline & & NADP & DF & RF \\
\hline Pearson & NADP & 1 & -0.09 & 0.21 \\
Correlation & DF & -0.094 & 1 & 0.25 \\
& RF & 0.213 & 0.252 & 1 \\
& NADP & & 0.253 & 0.06
\end{tabular}

\begin{tabular}{|c|c|c|c|c|}
\hline \multirow{2}{*}{$\begin{array}{l}\text { Sig. } \\
\text { tailed) }\end{array}$} & DF & 0.253 & . & 0.04 \\
\hline & $\mathrm{RF}$ & 0.064 & 0.036 & . \\
\hline \multirow{3}{*}{$\mathrm{N}$} & NADP & 52 & 52 & 52 \\
\hline & DF & 52 & 52 & 52 \\
\hline & $\mathrm{RF}$ & 52 & 52 & 52 \\
\hline
\end{tabular}

In the Table7, positive co-relationship exists between the Not-Adoption of HRIS and Restraining factors with the positive value .213 . Additionally it also shows negative co-relationship between Not-Adoption and Driving factors. Here the value is -.094 . Restraining factors lead to not adoption of HRIS while driving factors instigate the adoption.

Table 8Model summary ${ }^{\mathrm{b}}$

\begin{tabular}{|c|c|c|c|c|c|c|c|c|c|}
\hline \multirow[b]{2}{*}{ Model } & \multirow[b]{2}{*}{$\mathrm{R}$} & \multirow[b]{2}{*}{$\begin{array}{l}\mathrm{R} \\
\text { Square }\end{array}$} & \multirow[b]{2}{*}{$\begin{array}{l}\text { Adjuste } \\
\mathrm{d} \quad \mathrm{R} \\
\text { Square }\end{array}$} & \multirow{2}{*}{$\begin{array}{l}\text { Std. } \\
\text { Error of } \\
\text { the } \\
\text { Estimat } \\
\text { e }\end{array}$} & \multicolumn{5}{|c|}{ Change Statistics } \\
\hline & & & & & $\begin{array}{l}\text { R } \\
\text { Square } \\
\text { Change }\end{array}$ & $\begin{array}{l}\mathrm{F} \\
\text { Change }\end{array}$ & df1 & $\mathrm{df} 2$ & $\begin{array}{l}\text { Sig. F } \\
\text { Change }\end{array}$ \\
\hline 1 & $.263^{\mathrm{a}}$ & 0.069 & 0.031 & 1.154 & 0.069 & 1.814 & 2 & 49 & 0.174 \\
\hline
\end{tabular}

a. Predictors: (Constant), RF, DF

b. Dependent Variable: NADP

Table 9. ANOVA ${ }^{\mathrm{a}}$

\begin{tabular}{lllllll}
\hline Model & & Sum of Squares & df & Mean Square & F & Sig. \\
\hline 1 & Regression & 4.831 & 2 & 2.415 & 1.814 & $.174^{\mathrm{b}}$ \\
& Residual & 65.227 & 49 & 1.331 & & \\
& Total & 70.058 & 51 & & & \\
\hline
\end{tabular}

a. Dependent Variable: NADP

b. Predictors: (Constant), RF, DF 
Table 8 represents $\mathrm{R}$ square value .069 that refers how much the independent variables affect the dependent variable. Here the value indicates that the independent variables "Factors" positively affect the dependent variable "Adoption of HRIS" that has been represented through $\mathrm{F}$ value in Table 9.

Table 10. Coefficients ${ }^{\mathrm{a}}$

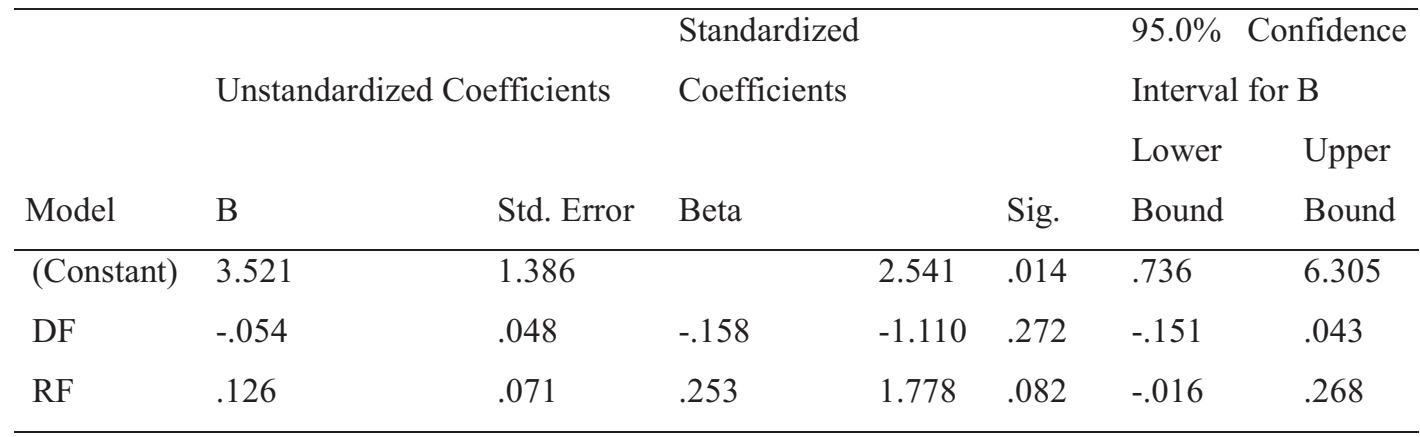

a. Dependent Variable: NADP

In the Table10, the value of B (Constant) 3.521 indicates average not-adoption of HRIS if there is no factor and the value of $B(R F) .126$ indicates the positive relationship between Not-Adoption and Restraining factors while value of $B$ (DF) -.054 shows the negative relationship between Driving factors and Not-Adoption of HRIS.

\subsubsection{Hypothesis testing: not-adoption of HRIS and driving factors}

$\mathrm{H} 0=\mathrm{No}$ significant relationship exists between Adoption of HRIS and Driving Factors.

$\mathrm{HA}=$ Significant relationship exists between Adoption of HRIS and Driving Factor

The calculated value of "t" of DF = 1.110. The critical value of " $t$ " at $5 \%$ level of significance is $+2.000 \&-2.000$. Here the calculated value of " $t$ " falls between these two critical values that show the acceptance of null hypothesis. So there is no significant correlation between Not-Adoption and Driving Factors as these factors lead to adoption.

\subsubsection{Hypothesis testing: not-adoption of HRIS and restraining factors}

$\mathrm{H} 0=\mathrm{No}$ significant relationship exists between Adoption of HRIS and Restraining Factors.

$\mathrm{HA}=$ Significant relationship exists between Adoption of HRIS and Restraining Fact

The calculated value of " $\mathrm{t}$ " of $\mathrm{RF}=$ 1.778. The critical value of $t$ at $5 \%$ level of significance is $+2.000 \&-2.000$. 
Here the calculated value of " $t$ " falls between these two critical values that indicate the acceptance of null hypothesis. So there is no significant correlation between not-adoption and restraining factors. Obviously restraining factors hinder the adoption of HRIS but organization can reduce these by taking different initiatives that can hinder these restraining factors. So not necessary that the relation between not-adoption and restraining factors will be significant as these can be reduced through proper initiatives. So this test shows the real picture of the situation of the organization.

\section{Conclusion and scope of future research}

Human resource information system is now a global practice and every organization is supposed to adopt this to survive in the competitive environment. The main focus of this study is to find out what is affecting to adopt human resource information systems in Bangladesh considering private banking sector collecting data through questionnaire distribution with sample size 52 respondents from 18 private banks operating in Bangladesh.

It took much time to get these 52 responses from the respondents. The study reveals both the positive and negative relationship between dependent and independent variable. Driving factors lead to the adoption of HRIS in banking sector as they are positively co-related and also hypothesis test shows the same results of positive relationship while restraining factors are negatively co-related with adoption that has been tested through building hypothesis. The another result has also been found that restraining factors lead to not-adoption of HRIS but hypothesis test reveals that this is not totally true for every time. These factors limit the adoption but by taking proper initiatives, this can be reduced to a greater extent especially in developing countries like Bangladesh.

The scope of the study is within the 18 private banks of Bangladesh that is the limitation of this study because there are many sectors that are adopting HRIS for better performance. Also there are many private banks remaining which have not been covered in this study only showing view from 18 private banks. The more will be the sample size, the more validity will be in the study. The study has been conducted with limited time. So it has missing the responses from large number of respondents and this study took only 52 sample size that needs to be increased for more valid results. Reviewing previous studies some specific factors have been chosen for this study skipping many other factors that significantly affect the adoption of 
HRIS. So future study can be conducted by considering the limitation of this study and this study will be fruitful for the future research.

In concluding part, it can be added that, in Bangladesh HRIS should be considered as the significant issue for competing in this technology based world. As like banking sector, other sector has now started to adopt HRIS to explore the various benefits of this that is the symptom of the better situation for the country to compete with others in this competitive world. So the affecting factors should be considered for adopting Human Resource Information Systems in organizations.

\section{References}

Alshibly, Haitham. (2011). "Human Resources Information Systems success Assessment: An integrative model", Australian Journal of Basic and Applied Sciences. 5(5), 157-169.

Al-Zu'bi, Zu'bi. (2013). "Factors Influencing the Adoption of HRIS Applications: A Literature Review", International Journal of Management and Business Studies (IJMBS). 3. 9-26.

Ambira, C.M., \&Kemoni, H., (2011), "Records management and risk management at Kenya Commercial Bank Limited", South African Journal of Information Management, 13(1).92102.

Arpaci, I, Cetin Yardimci, Y, Ozkan, S ,
Turetken,O.(2012). “ORGANIZATIONAL ADOPTION OF INFORMATION TECHNOLOGIES: A LITERATURE REVIEW", International Journal of e Business and e Government Studies , 4 (2), 37-50 .

Bhuiyan, M. R. U., \&Rahman, R. (2014). "Application of Human Resource Information System in the Firms of Bangladesh and Its Strategic Importance", World Review of Business Research, 4(3), 95-105.

Broderick, R., \&Boudreau, J. W. (1991). "Human resource management, information technology, and the competitive edge" ,CAHRS Working Paper, 19-91.

Chau, P.Y.K. and Tam, K.Y. (1997), "Factors affecting the adoption of open systems: an exploratory study", MIS Quarterly, Vol. 21 No. 1, 1-24.

Dery K., Grant, D, Wiblen, S (2009). "HUMAN RESOURCE INFORMATION SYSTEMS (HRIS): REPLACING OR ENHANCING HRM".

Dessler, Gary, (2012), "Human Resource Management", Bookbarn International.

Florkowski, G.W., \&Olivas-Luján, M.R. (2006)."The diffusion of humanresource information-technology innovations in US and non-US firms". Personnel Review, 35(6), 684-710.

Ginzberg, M. J. (1981). "Early diagnosis of MIS implementation failure: Promising results and unanswered questions", Management Science, 27, 459-478.

Greenhaus, Jeffrey H., Callanan, Gerard A., Godshalk, V. (2006), "Career Management”, SAGE Publications.

Hanif, Muhammad. (2014). "Explore the Adoption of HRIS in Telecom Sector in Pakistan", International Journal of 
Economics and Management Sciences, Vol. 3(2): 1-10.

Hendrickson, A.R. (2003). "Human Resource Information Systems: Backbone Technology of Contemporary Human Resources", Journal of Labor Research, 24, 382-394.

Iacovou, C. L., Benbasat, I., \& Dexter, A. S. (1995). "Electronic data interchange and small organizations: Adoption and impact of technology", MIS Quarterly, 465-485.

Jahan, S. (2014) "Human Resources Information System (HRIS): A Theoretical Perspective", Journal of Human Resource and Sustainability Studies, 2, 33-39.

Khan, A. R., Hasan, N. \&Rubel, M. (2015). "Factors Affecting Organizations Adopting Human Resource Information Systems: A Study in Bangladesh", IOSR Journal of Business and Management. 17.45-54.

King, W. R., \&Teo, T. S. H. (1996).“Key dimensions of facilitators and inhibitors for the strategic use of information technology", Journal of Management Information Systems, 35-53.

Maier, C., et al(2012),. "Analyzing the impact of HRIS implementations on HR personnel's job satisfaction andturnover intention", J. Strateg. Inform. Syst, 1-15.

Ngai, E., \&Wat, F. (2006)."Human resource information systems: a review and empirical analysis", Personnel Review, 35(3), 297-314.

Normalini, ., Kassim, ., Ramayah, T. and Kurnia, S. (2012), "Antecedents and outcomes of human resource information system (HRIS) use", International Journal of Productivity and Performance Management, Vol. 61 No. 6,. 603-623.

Rahman, M., Qi, X. and Jinnah, M. (2016)."Factors affecting the adoption of HRIS by the Bangladeshi banking and financial sector", Cogent Business \& Management, 3(1), 1-10.

Tannenbaum, S.I. (1990). “ Human Resource Information Systems: User Group Implications", Journal of Systems Management, 41, 27-32.

Teo, T. S., \&Pian, Y. (2003).“A contingency perspective on internet adoption and competitive advantage", European Journal of Information Systems, 12(2), 78-92.

Tornatzky, L. G., \& Klein, K. J. (1982)."Innovation characteristics and innovation adoption-implementation: A meta-analysis of findings", IEEE Transactions on Engineering Management, 29(1), 28-45.

Troshani, I., Jerram, C. and Rao Hill, S. (2011), "Exploring the public sector adoption of HRIS", Industrial Management \& Data Systems, Vol. 111 No. 3, 470-488.

Venkatesh, V., Morris, M.G., Davis, G.B., Davis, F.D., 2003."User acceptance of information technology: toward a unified view", MIS Quarterly 27 (3), 425-478.

Zhang, L., \&Wang, H. (2006).“Intelligent information processing in human resource management: an implementation case in China", Expert Systems, 23, 356-369. 


\section{Appendix}

\section{Frequency distribution table:}

\begin{tabular}{|c|c|c|c|c|c|c|}
\hline \multirow[t]{2}{*}{ Factors } & \multirow[t]{2}{*}{ Statements } & 1 & 2 & 3 & 4 & 5 \\
\hline & & $\begin{array}{l}\text { Strongly } \\
\text { Disagree }\end{array}$ & Disagree & Neutral & Agree & $\begin{array}{l}\text { Strongly } \\
\text { Agree }\end{array}$ \\
\hline \multirow[t]{7}{*}{ Driving factors } & $\begin{array}{l}\text { HRIS expertise and knowledge play } \\
\text { a great role in adoption of HRIS }\end{array}$ & $\begin{array}{l}1.9 \% \\
(1)\end{array}$ & $\begin{array}{l}0 \% \\
(0)\end{array}$ & $\begin{array}{l}17.3 \% \\
(9)\end{array}$ & $\begin{array}{l}38.5 \% \\
(20)\end{array}$ & $\begin{array}{l}42.3 \% \\
(22)\end{array}$ \\
\hline & $\begin{array}{l}\text { Better IS infrastructure drives } \\
\text { adoption }\end{array}$ & $\begin{array}{l}0 \% \\
(0)\end{array}$ & $\begin{array}{l}0 \% \\
(0)\end{array}$ & $\begin{array}{l}13.5 \% \\
(7)\end{array}$ & $\begin{array}{l}44.2 \% \\
(23)\end{array}$ & $\begin{array}{l}42.3 \% \\
(22)\end{array}$ \\
\hline & $\begin{array}{l}\text { Support of higher authority } \\
\text { instigates adoption of HRIS }\end{array}$ & $\begin{array}{l}0 \% \\
(0)\end{array}$ & $\begin{array}{l}1.9 \% \\
(1)\end{array}$ & $\begin{array}{l}5.8 \% \\
(3)\end{array}$ & $\begin{array}{l}30.8 \% \\
(16)\end{array}$ & $\begin{array}{l}61.5 \% \\
(32)\end{array}$ \\
\hline & $\begin{array}{l}\text { External network availability leads } \\
\text { to the adoption }\end{array}$ & $\begin{array}{l}1.9 \% \\
(1)\end{array}$ & $\begin{array}{l}3.8 \% \\
(2)\end{array}$ & $\begin{array}{l}26.9 \% \\
(14)\end{array}$ & $\begin{array}{l}50 \% \\
(26)\end{array}$ & $\begin{array}{l}17.3 \% \\
(9)\end{array}$ \\
\hline & $\begin{array}{l}\text { Competitive environment where } \\
\text { other banks are using HRIS }\end{array}$ & $\begin{array}{l}0 \% \\
(0)\end{array}$ & $\begin{array}{l}1.9 \% \\
(1)\end{array}$ & $\begin{array}{l}23.1 \% \\
(12)\end{array}$ & $\begin{array}{l}42.3 \% \\
(22)\end{array}$ & $\begin{array}{l}32.7 \% \\
(17)\end{array}$ \\
\hline & $\begin{array}{l}\text { Better performance and quality } \\
\text { service of HRIS intend the } \\
\text { organizations to adopt HRIS }\end{array}$ & $\begin{array}{l}0 \% \\
(0)\end{array}$ & $\begin{array}{l}0 \% \\
(0)\end{array}$ & $\begin{array}{l}11.5 \% \\
(6)\end{array}$ & $\begin{array}{l}51.9 \% \\
(27)\end{array}$ & $\begin{array}{l}36.5 \% \\
(19)\end{array}$ \\
\hline & $\begin{array}{l}\text { Bangladesh government regulation } \\
\text { supports the adoption of HRIS }\end{array}$ & $\begin{array}{l}13.5 \% \\
(7)\end{array}$ & $\begin{array}{l}19.2 \% \\
(10)\end{array}$ & $\begin{array}{l}32.7 \% \\
(17)\end{array}$ & $\begin{array}{l}23.1 \%( \\
12)\end{array}$ & $\begin{array}{l}11.5 \% \\
(6)\end{array}$ \\
\hline \multirow[t]{3}{*}{$\begin{array}{l}\text { Restraining } \\
\text { factors }\end{array}$} & $\begin{array}{l}\text { Resistance from employees restrains } \\
\text { HRIS adoption }\end{array}$ & $\begin{array}{l}3.8 \% \\
(2)\end{array}$ & $\begin{array}{l}15.4 \% \\
(8)\end{array}$ & $\begin{array}{l}32.7 \% \\
(17)\end{array}$ & $\begin{array}{l}36.5 \% \\
(19)\end{array}$ & $\begin{array}{l}11.5 \% \\
(6)\end{array}$ \\
\hline & $\begin{array}{l}\text { Complexity in usage system provide } \\
\text { hindrance }\end{array}$ & $\begin{array}{l}3.8 \% \\
(2)\end{array}$ & $\begin{array}{l}11.5 \% \\
(6)\end{array}$ & $\begin{array}{l}28.8 \% \\
(15)\end{array}$ & $\begin{array}{l}38.5 \% \\
(20)\end{array}$ & $\begin{array}{l}17.3 \% \\
(9)\end{array}$ \\
\hline & $\begin{array}{l}\text { Higher cost limits the HRIS } \\
\text { adoption in developing countries } \\
\text { like Bangladesh }\end{array}$ & $\begin{array}{l}3.8 \% \\
(2)\end{array}$ & $\begin{array}{l}11.5 \% \\
(6)\end{array}$ & $\begin{array}{l}15.4 \% \\
(8)\end{array}$ & $\begin{array}{l}36.5 \% \\
(19)\end{array}$ & $\begin{array}{l}32.7 \% \\
(17)\end{array}$ \\
\hline \multirow[t]{2}{*}{$\begin{array}{l}\text { Adoption of } \\
\text { HRIS }\end{array}$} & $\begin{array}{l}\text { Organization are adopting HRIS to } \\
\text { facilitate with driving factors }\end{array}$ & $\begin{array}{l}5.8 \% \\
(3)\end{array}$ & $\begin{array}{l}5.8 \% \\
(3)\end{array}$ & $\begin{array}{l}15.4 \% \\
(8)\end{array}$ & $\begin{array}{l}51.9 \% \\
(27)\end{array}$ & $\begin{array}{l}21.2 \% \\
(11)\end{array}$ \\
\hline & $\begin{array}{l}\text { Organization are not adopting HRIS } \\
\text { for restraining factors }\end{array}$ & $\begin{array}{l}7.7 \% \\
(4)\end{array}$ & $\begin{array}{l}15.4 \% \\
(8)\end{array}$ & $\begin{array}{l}26.9 \% \\
(14)\end{array}$ & $\begin{array}{l}32.7 \% \\
(17)\end{array}$ & $\begin{array}{l}17.3 \% \\
(9)\end{array}$ \\
\hline
\end{tabular}

Source: Field survey 